\title{
Religious Actors in the European Union*
}

\author{
Lucian N. Leustean \\ Aston Centre for Europe, Aston University, Birmingham
}

Summary: I. Introduction.-II. A Typology of Religious/Convictional Relations. 1. Public-Private Relations. 2. Experimental Relations. 3. Proactive Relations. 4. Institutionalised Relations. - III. The Functional Breakdown of Representations. 1. Diplomatic representations. 2. Official representations of churches. 3. Inter-Church or Convictional Organisations/Networks. 4. Religious orders. 5. Single-issue organisations. - IV. Conclusion.

\begin{abstract}
Article 17 of the Lisbon Treaty institutionalises an 'open, transparent and regular dialogue' between European institutions and churches, religions and communities of conviction. This article examines the functional breakdown of religious dialogue in the European Union and proposes four types of relations between religious/convictional representations and European institutions, namely, private-public, experimental, proactive and institutionalised.

Keywords: Religion; European Union; A Typology of Religious Actors; Religious Dialogue; European Institutions.

Resumen: El artículo 17 del Tratado de Lisboa institucionaliza «un diálogo abierto, transparente y habitual» entre las instituciones europeas e «iglesias, religiones y comunidades de convicción». Este artículo examina la ruptura funcional del diálogo religioso en la Unión Europea y propone cuatro tipos de relaciones entre las representaciones religiosas o de convicción y las instituciones europeas: privadas o públicas, experimentales, proactivas e institucionalizadas.

Palabras clave: Religión, Unión Europea, una tipología de actores religiosos, diálogo religioso, instituciones europeas.
\end{abstract}

\section{Introduction}

On 1 July 1968 President Jean Rey of the European Commission made a public declaration announcing a new stage in the process of European integration, namely the completion of the Customs Union. Endorsing the latest transnational political and economic achievements of the six members of the European Community (EC), he noted that, '1 July 1968 will certainly go down as a milestone in the history of Europe [...] the major stage on the road to the economic unification of the European continent will be complete'. President Rey encouraged 'Europeans not to ignore or underestimate the

* Recibido el 2 de noviembre de 2012, aceptado el 18 de diciembre de 2012. 
importance of what is now happening' and, indicated that his declaration, in the name of the whole European Commission, should be perceived as 'an act of faith, an expression of hope and an action programme'. He closed his speech by making a rather unusual reference to churches, arguing that,

Two great spiritual developments dominate this second half of the twentieth century: the reconciliation of the churches and the reconciliation of the peoples. The first is not a political matter, but the second is our affair. The reconciliation of peoples has been first and foremost the reconciliation of European nations, ravaged by the two World Wars of 1914-1918 and 1939-1945, both born in Europe of the clash of nationalisms: for the peoples of Europe these were genuine civil wars. This time is now past. The moment has come to call the young and creative forces of Europe to union, action and hope'. ${ }^{1}$

At first glance, President Rey's words seemed to be in line with other comments on religion made by politicians across Western Europe. Christian democratic parties have regularly brought together a wide range of political leaders endorsing closer cooperation between countries while also making references on religion. ${ }^{2}$ Rey's statement was not aimed at instigating a spiritual reawakening on the increasing secularized continent, but at acknowledging the role of 'faith' in the reconciliation between peoples. ${ }^{3}$

A comparable engagement with issues related to 'faith' would not take place until after the fall of communism, in 1990, when President Jacques Delors of the European Commission encouraged representatives of churches, religions and non/philosophical associations to reconsider the 'soul and heart of Europe'. Delors's words resonated among religious leaders particularly when he claimed that, without finding 'the heart of Europe, [...] in the next ten years $[\ldots]$ the game will be up'. ${ }^{4}$

${ }^{1}$ Declaration by the Commission of the European Communities, 1 July 1968. Full text available at http://www.ena.lu/ (accessed 28 January 2011).

${ }^{2}$ For Christian democracy and the European Community see KAISER, W., Christian Democracy and the Origins of the European Union, Cambridge University Press, Cambridge, 2007; VAN HECKE, S. and GERARD, E. (eds.), Christian Democratic Parties in Europe since the End of the Cold War, Leuven University Press, Leuven, 2004.

3 For secularization in post-war Europe see MARTIN, D., A General Theory of Secularisation, Blackwell, Oxford, 1978; BERGER, P. (ed.), The Desecularization of the World: Resurgent Religion and World Politics, W.B. Eerdmans, Grand Rapids, MI, 1999; CASANOVA, J., Public Religions in the Modern World Chicago University Press, Chicago, 1994; BERGER, P., DAVIE, G. and FOKAS, E., Religious America, Secular Europe? A Theme and Variations, Ashgate, London, 2008.

${ }^{4}$ For the religious and political context of President Delors's reference to the 'heart and soul of Europe' see LEUSTEAN, L.N., "Does God Matter in the European Union?" in LEUSTEAN, L.N., Representing Religion in the European Union. Does God Matter?, Routledge, London, 2012. 
For the most part of their existence, European institutions have been silent on religion..$^{5}$ The European Union did not issue an official view on religious and convictional issues until the 1997 Amsterdam Treaty (Declaration 11). A revised form of this Declaration was incorporated in Article 17 of the 2009 Lisbon Treaty which went a step further and institutionalised an 'open, transparent and regular dialogue' between European institutions and churches, religions and communities of conviction. ${ }^{6}$

This article sets out the typology of religious and convictional actors in the European Union and addresses the following questions: In what religious and political context have references to religion emerged in the European Union? Who are the main actors involved in religious dialogue with European institutions? Do President Rey's and Delors's words represent only a private 'act of faith' or the result of an on-going dialogue between European institutions and religious/convictional communities?

\section{A Typology of Religious/Convictional Relations ${ }^{7}$}

\section{Public-Private Relations}

Public-private relations were the prime feature of the dialogue between churches and European institutions after the 1950 Schuman Declaration. This type of relations emerged due to the personal interest in religious issues

${ }^{5}$ For religion and politics in contemporary Europe see CHENAUX, P., De la chrétienté a l'Europe. Les catholiques et l'idée européenne au XXe siècle, CID Editions, Tours, 2007; NELSEN, B.F., GUTH, J.L. and FRASER, C.R., "Does Religion Matter? Christianity and Public Support for the European Union”, European Union Politics, 2001, 2 (2), pp. 191-217; BYRNES, T.A. and KATZENSTEIN, P.J., (eds.) Religion in an Expanding Europe, Cambridge University Press, Cambridge, 2006; DAVIE, G., Religion in Modern Europe: a Memory Mutates, Oxford University Press, Oxford, 2000; DAVIE, G., Europe, The Exceptional Case. Parameters of Faith in the Modern World, Longman and Todd, Darton, 2002; NORIS, P. and INGLEHART, R., Sacred and Secular: Religion and Politics Worldwide, Cambridge University Press, Cambridge, 2004; FORET, F. and RIVA, V., "Religion between Nation and Europe: The French and Belgian 'No' to the Christian Heritage of Europe", West European Politics, 2010, 33 (4), pp. 791-809; FORET, F. and SCHLESINGER, P., "Political Roof and Sacred Canopy? Religion and the EU Constitution", European Journal of Social Theory, 2006, 9 (1), pp. 59-81.

${ }^{6}$ Article 17 states that: 'The Union respects and does not prejudice the status under national law of churches and religious associations or communities in the Member States. The Union equally respects the status under national law of philosophical and non-confessional organisations. Recognising their identity and their specific contribution, the Union shall maintain an open, transparent and regular dialogue with these churches and organisations'.

7 The following two sections draw on LEUSTEAN, L.N., "Representing Religion in the European Union. A Typology of Actors", Politics, Religion and Ideology, 2011, 12 (3), pp. 295-315 which details the religious typology and includes a list of religious/convictional actors in dialogue with European institutions. 
among civil servants and politicians working in or associated with European institutions rather than a pan-European policy on religion. After the Schuman Declaration and the establishment of the European Coal and Steel Community (ECSC), the first six member-states resembled a predominantly Catholic bloc. However, despite this perception, transnational Protestant political networks which developed from interwar ecumenical relations produced the first Christian reflection group examining the impact of European cooperation on churches. ${ }^{8}$ This group, named the 'Ecumenical Commission on European Cooperation' (ECEC), was established in September 1950 only a few months after the Schuman Declaration and lasted until 1974. It was chaired by André Philip, former minister in Charles de Gaulle's provisional government, and Connie L. Patijn, the Dutch delegate to the United Nations Economic and Social Council, and had a highly selective membership bringing together churchmen, politicians and civil servants. The rapid mobilisation of Protestant networks was due to the active influence of the World Council of Churches (WCC) which held its first Assembly in 1948 in Amsterdam.

The ECEC brought together a significant number of religious and political leaders from both the ECSC member states and other West European countries, including United Kingdom, Norway, Austria and Switzerland. It encouraged Protestant and Anglican churches to reflect on the process of European cooperation and issued reports which were distributed on both sides of the Atlantic. The failure of wider Protestant mobilisation towards the process of European cooperation was due to emerging Cold War tensions between East and West and the organisational nature of the WCC. A number of WCC leaders were reluctant to express official support for the ECEC, fearing that the endorsement of a regional political project could endanger worldwide relations between churches.

Despite the limited public discussion among Protestant and Anglican churches on the nature of the ECSC in the 1950s and the 1960s, the ECEC had a double impact. Firstly, it brought together Protestant clergymen and politicians from the United States and Western Europe to discuss the role of post-war international organisations. From the beginning, its membership was not only limited to the ECSC member states but also included the United Kingdom and Nordic countries which took an active part in discussions on transnational religious and political issues. Secondly, some ECEC members would later become public political figures, some of whom had a direct

${ }^{8}$ GRESCHAT, M. and LOTH, W. (eds), Die Christen und die Enstehung der Europäischen Gemeinschaft Kohlhammer, Stuttgart, 1994; ZEILSTRA, J., European Unity in Ecumenical Thinking 1937-1948 Boekencentrum, Zoetermeer, 1995; LEUSTEAN, L.N., "The Ecumenical Movement and the Schuman Plan, 1950-54”, Journal of Church and State, 2011, 53 (3), pp. $442-71$. 
input on the shaping of Western national and transnational politics, such as Gustav Heinemann, President of the Federal Republic of Germany, Jean Rey, President of the European Commission, and Max Kohnstamm, Secretary to the High Authority of the European Coal and Steel Community. These leaders regarded churches as playing a prime role in the process of reconciliation and cooperation rather than as actors directly involved in the political mechanism of European integration.

In addition to providing a discussion forum on religious and political issues, the ECEC members were instrumental in supporting the establishment of religious bodies representing Protestant and Anglican churches in the European Community, namely the 'Consultative Committee of Churches in the European Communities' (1964), and the Ecumenical Centre in Brussels (1966). Both the Committee and the Centre emerged with ECEC support and also as a result of civil servants working in Brussels who encouraged their churches to send representatives to European institutions.

Relations between European institutions and the Roman Catholic Church developed on the initiative of local dioceses, at least in France and Belgium, rather than as a systematic policy of the Holy See towards European federalism. Between 1950 and 1952 the diocese in Strasbourg had a small office monitoring the Council of Europe; however, the office was closed due to financial reasons. A new office was opened by Jesuit clergy in Strasbourg in 1956 which aimed to provide a link between the Council of Europe and the Roman Catholic Church. This office, named the 'Catholic European Study Information Centre' (Office Catholique d'Information sur les Problèmes Européens or OCIPE), opened a branch in Brussels in 1963. OCIPE ran in parallel with the 'European Catholic Centre' (Foyer Catholique Européenne) which was established in the same year to look after the pastoral needs of EC officials and their families in Brussels. ${ }^{9}$

After the Second Vatican Council a large number of religious bodies entered into contact with European institutions, some of which opened offices in Brussels to provide expertise and a global network on education, development, humanitarian aid and diplomatic relations, such as the CIDSE - International Co-operation for Development and Solidarity in 1967; the Catholic International Education Office in 1974; and, the European Committee for Catholic Education in 1974. The increasing number of Catholic offices in Brussels was supported by the appointment of a Papal Nuncio in charge of diplomatic relations between the Holy See and the European Community in 1970.

The first elections to the European Parliament in 1979 led to further developments in the presence of religious communities in Brussels. In

9 DE CHARENTENAY, P., "Les relations entre l'Union européenne et les religions", Revue du Marché commun et de l'Union européenne, 2003, No. 465, pp. 90-100. 
1979 the Quaker Council for European Affairs opened an office while, in the following year, the Holy See established an official representation, 'the Commission of Bishops' Conferences of the European Community' (COMECE), which provided a direct link between Catholic bishops in the European Community and European institutions.

Both the Catholic and Protestant offices in Brussels and Strasbourg operated with a small number of personnel, mainly appointed by national religious bodies, and with limited financial support from their churches and from the European Commission. These offices brought together not only churchmen from EC member states but also civil servants working in European institutions who provided expertise in areas traditionally considered outside the interest of churches, such as agriculture and migration. This exchange of information and knowledge between churches and European institutions reflected the private-public nature of religion. The concept of religion was associated with the personal interests of some EU officials while religious representations were regarded as part of the increasing number of civil society organisations lobbying in Brussels.

The involvement of EC civil servants in religious representations had a double impact. Firstly, it led to increased contact between Catholic and Protestant offices marked by the 1974 Roehampton Conference. The Conference represented the climax of inter-religious relations in Western Europe and was dedicated to the process of European integration. Secondly, the Conference instigated the establishment of a Joint Protestant-Catholic Working Group in Brussels to provide a theoretical investigation of the 'purpose' (finalité) of European integration. In addition, religious dialogue led to an established representation in Brussels named the 'European Ecumenical Commission on Development' (EECOD) which ran from 1975 to 1996.

\section{Experimental Relations}

The second type of relations developed due to the decision of President Gaston Thorn to establish an 'experimental' contact between the European Commission and churches in June 1982. On the recommendation of Secretary General Émile Noël, Thorn appointed Umberto Stefani, Director at the Secretariat General, as Special Counsellor on 13 September 1983 in charge of compiling a census of religious organisations and as an informal liaison officer with the Holy See. Stefani retained this position during the first years of Jacques Delors's presidency and was instrumental in organising the visits of Pope John Paul II to European institutions in 1985 and 1988.

The experimental type of relations was fuelled both by Delors's interest in religious and ethical issues and by the increasing mobilisation of religions 
on European issues in the context of the Single European Act and the establishment of a Single Market. New religious bodies set up offices in Brussels and engaged in informal dialogue. These included the European Union of Jewish Students which opened an office in 1982, while the European Commission received delegations from the European Jewish Congress in 1987 and the Ecumenical Patriarchate in 1989.

After the death of Jean-Louis Lacroix, who worked on ethical issues and was one of Delors's closest advisors, Delors appointed the so-called 'Lacroix Group' of advisors in 1987. Although the group did not have an official mandate to liaise with churches, on 8 March 1989 Delors established a new advisory group named the 'Forward Studies Unit' (FSU) (Cellule de prospective) under the leadership of Jean-Claude Morel, a former General Director, and Jérôme Vignon, Coordinator of Studies. The FSU continued the Lacroix Group's previous expertise and was asked to establish regular contact with churches and religious communities.

\section{Proactive Relations}

The FSU's official mandate on religion led to the appointment of Marc Luyckx as Secretary in charge of religious dialogue in September 1990. Luyckx, a former Catholic priest with a doctorate in Russian and Greek theology from the Pontificio Istituto Orientale, previously served as Secretary of the EECOD from 1985 until 1989. In 1990 he wrote a comparative analysis of the Abrahamic religions and atheist communities and concluded that, despite the process of secularisation, there was an increasing interest in spirituality coupled with science and technology.

His drive in favour of closer relations between the Commission and a wide range of religious and convictional communities that needed to be better organised at the pan-European level was paralleled by a large number of new religious representations. They included churches (the Brussels Office of the Evangelical Church in Germany in 1990; the Jesuit Refugee Service Europe in 1991; the Liaison Office of the Orthodox Church to the European Union in 1994, under the jurisdiction of the Ecumenical Patriarchate), religions (CEJI - A Jewish Contribution to an Inclusive Europe in 1990; the Forum of European Muslim Youth and Student Organization in 1996; the European Bahá'í Business Forum in 1993) and communities of conviction (European Humanist Federation in 1991).

In October 1996, Luyckx was replaced by Thomas Jansen, SecretaryGeneral of the European People's Party, who retained his position during Santer's presidency. In the same year, the Forward Studies Unit was renamed as the Group of Political Advisors to the European Commission 
(GOPA). ${ }^{10}$ During Romano Prodi's presidency, Michael Weninger, a former Austrian diplomat with studies in theology and philosophy was appointed in charge of contact with churches and religious communities within the GOPA. ${ }^{11}$

Both Jansen's and Weninger's leaderships coincided with the establishment of 'A Soul for Europe: Ethics and Spirituality', an initiative of the European Commission, which was intended to promote religious dialogue between Christians, Jews, Muslims and Humanists and was administered by the European Ecumenical Commission for Church and Society. The programme had its origins in Delors's meeting with religious leaders in 1990 in which he suggested that Europe needed 'a soul'.

The establishment of the Convention on the Future of Europe in 2001 and discussions on the Treaty Establishing a Constitution for Europe brought new religious actors in contact with European institutions. The decision to exclude references to 'God' and 'Christianity' in the Preamble of the Constitution, and debates in the intergovernmental conference between 2003 and 2004 revealed that, despite an increase in religious lobbying in Brussels, national governments continued to have a powerful voice on issues related to religion.

\section{Institutionalised Relations}

The institutionalisation type of religious relations has been the product of intergovernmental negotiations during the Convention and increased the significance of religious dialogue between European institutions and churches, religions and communities of conviction (Article 17 of the Lisbon Treaty). In 2005 the Group of Political Advisors was renamed the Bureau of European Policy Advisors. In 2007 Jorge César das Neves, a Portuguese official with a background in philosophy, was appointed in charge of its relations with religions/convictional communities; in January 2012 he was replaced by Katharina von Schnurbein, a German national who was previously the European Commission's Spokesperson for Employment, Social Affairs and Equal Opportunities and Chair of the European Affairs Committee at the German Bundestag in Berlin. The institutionalisation of religious dialogue is in line with President José Manuel Barosso's approach to issues of 'faith', resulting in annual meetings between the Commission and high-profile leaders from a large number of religious and convictional bodies.

10 JANSEN, T., "Europe and Religions: the Dialogue between the European Commission and Churches or Religious communities", Social Compass, 2000, 47 (1), pp. 103-12.

11 WENINGER, M.H., Europa ohne Gott? Die Europäische Union und der Dialog mit den Religionen, Kirchen und Weltanschauungsgemeinschaften, Nomos, Baden-Baden, 2007. 


\section{The Functional Breakdown of Representations}

Religious representations in the European Union are divided into diplomatic representations; official representation of churches; inter-church organisations or networks; confessional or convictional organisations; religious orders; and single-issue organisations.

\section{Diplomatic representations}

The Roman Catholic Church is the only religious confession with a diplomatic representation in Brussels, and has a Papal Nuncio for the European Community, first appointed in 1970. According to diplomatic law, the Papal Nuncio not only represents the Holy See but also has a symbolic mission as the Doyen of the Diplomatic Corps accredited in Brussels. Concurrent with the increased number of representations after the Maastricht Treaty, the Order of Malta entered into contact with the European Commission in the early 1990s and opened a diplomatic representation in 2003. However, the Order of Malta is not recognised by all EU member states; its diplomatic relations are recognised only by the European Commission and not by the other European institutions. In 2006 the European Commission opened an EU diplomatic delegation to the Holy See and, in the following year, the delegation was given diplomatic attributions regarding the Order of Malta.

\section{Official representations of churches}

A distinct entity is the 'official representation of churches'. Churches have been firstly represented by either pastoral bodies or by inter-church organisations. Although the Catholic Church was in contact with European institutions through OCIPE, the European Catholic Centre and other Catholic agencies, it opened its 'official' representation only in 1980, namely the COMECE. The COMECE is in direct contact with a large number of Catholic bodies and represents the official voice of the Roman Catholic Church to European institutions.

The first Protestant church to have an independent office was the Evangelical Church of Germany (Evangelischen Kirche in Deutschland EKD) in 1990. The office provides legal expertise to the Church and Society Commission of the Conference of European Churches (CSC/CEC) and represents the EKD to European institutions.

After the Maastricht Treaty, a large number of churches followed a similar pattern to the EKD. Although they were and remained part of inter- 
church structures, they have gradually opened their own offices. In some cases, churches have chosen to become more visibly part of the structure of an inter-church organisation by sending an officer to represent them in Brussels (for example, representatives from Sweden and Finland working in the CSC/CEC). Other churches have decided to maintain contact with their previous inter-church partners while setting up offices of their own, such as the Ecumenical Patriarchate (1994), the Orthodox Church of Greece (1998), the Romanian and the Cypriot Orthodox Churches (2007) and the Church of England (2008).

\section{Inter-church/convictional organisations/networks}

Inter-church organisations/networks have a large membership and represent most confessions within a specific branch of a faith. Since their establishment the World Council of Churches (1948) and the Conference of European Churches (1959) have had informal contact with the Ecumenical Centre in Brussels. In addition, some inter-church networks have separated from these organisations and established their own representations, such as the European Evangelical Alliance (1994) and the Pentecostal European Fellowship (2005).

A number of non-Christian and convictional communities have established their own offices in Brussels. The main distinction between this type of structure and those above is in their membership. The confessional/ convictional organisations/networks represent either only a community within a larger confession (for example, B'nai B'rith Europe) or a group of confessional/convictional organisations (for example, the European Union of Jewish Students or the European Humanist Federation). ${ }^{12}$

\section{Religious orders}

Religious orders do not fit into one of the above categories due to their nature and operation. Their prime activity is pastoral, some of them carrying out advocacy work which is independent of the official policy of their Churches. In particular, the Jesuit order has been the most active in monitoring the activities of European institutions, opening a religious office in Strasbourg in 1956 and in Brussels in 1963. A European office of the Jesuit

${ }^{12}$ For Islamic communities in dialogue with European institutions see SILVESTRI, S., "Islam and Religion in the Political System of the EU", West European Politics, 2009, 32 (6), pp. 1210-1239. 
Refugee Service was opened in 1990 while the Dominican order established a centre (ESPACES - Spirituality, Culture and Society in Europe) in 2001.

\section{Single-issue organisations}

The majority of religious and convictional organisations represent single-issue groups, such as education, humanitarian aid and advocacy. They operate either on an exclusive 'single' issue or are engaged in a few issues at the same time. The single-issue organisations span across all churches, religions and communities of convictions and are actively engaged in EU policy areas. Most of them are in dialogue with European institutions either through diplomatic representation, official representation of churches or inter-church or convictional organisations/networks. For example, the majority of Christian single-issue organisations maintain close relations and are represented by the COMECE and the CSC/CEC in their dialogue with European institutions.

\section{Conclusion}

The Lisbon institutionalisation of religious dialogue builds on extensive relations between European institutions and religious/convictional actors over many years. Although the number of representations in Brussels increased considerably after the Maastricht Treaty, European civil servants have engaged in religious dialogue since the very first days of the European Community. This dialogue has been shaped by four types of relations between European institutions and religious/convictional communities, namely private-public, experimental, proactive and institutionalised.

Each type has been encouraged by the European Commission's engagement on issues of 'faith' with religious issues remaining under the legal jurisdiction of the EU member states rather than part of a supra-national policy on religion. ${ }^{13}$ The increasing diversity of the functional breakdown of religious/convictional representations in dialogue with European institutions

${ }^{13}$ For relations between religious communities and European institutions see ROBBERS, G. (ed.), State and Church in the European Union, Nomos, Baden-Baden, 1996; MASSIGNON, B., Des dieux et des fonctionnaires. Religions et laïcités face au défi de la construction européenne, Presses Universitaires de Rennes, Rennes, 2007; MCCREA, R., Religion and the Public Order of the European Union, Oxford University Press, Oxford, 2010; and LEUSTEAN, L.N. and MADELEY, J.T.S. (eds.), Religion, Politics and Law in the European Union, Routledge, London, 2010. 
suggests a shift from the national to supranational approach towards religion. This shift has been encouraged by the soft-policy engagement of the European Commission with civil society organisations. Taking into account the functional breakdown of religious/convictional representations in the European Union, single-issue organisations have become the driving force of implementing a transnational public policy in which issues of 'religion' and 'faith' are actively associated with socio-economic projects at the national level of EU member states. 